Our Nature (2011) 9: 83-88

\title{
Effect of Cadmium Chloride on the Histoarchitecture of Certain Organs of a Freshwater Catfish, Clarias batrachus
}

\author{
B.A. Dar ${ }^{*}$, T.A. Qureshi and R. Khaliq \\ Department of Zoology and Applied Aquaculture, Barkatullah University, Bhopal \\ EE-mail: bilalaqua@gmail.com
}

Received: 09.07.2011, Accepted: 28.11.2011

\begin{abstract}
The present study was conducted to investigate the effects of cadmium chloride induced histological alterations in the liver and kidney of a freshwater catfish, Clarias batrachus. The fishes were exposed to $4 \mathrm{ppm}\left(4 \%\right.$ of $\left.96 \mathrm{~h} \mathrm{LC}_{50}\right)$ and $8 \mathrm{ppm}\left(8 \%\right.$ of $\left.96 \mathrm{~h} \mathrm{LC}_{50}\right)$ of cadmium chloride for 60 days. The most common changes in liver at all doses of cadmium chloride were loosening of hepatic tissue, vacuolated cell cytoplasm, enucleation and eccentric nuclei. In the kidney of fish exposed cadmium chloride were characterized by loosening of haemopoietic tissue, uriniferous tubules have lost their original appearance, vacuolated cytoplasm, degeneration in the epithelial cells of renal tubule, narrowing of the tubular lumen and damaged glomeruli.
\end{abstract}

Key words: Cadmium chloride, histopathology, Clarias batachus, liver, kidney.

\section{Introduction}

The availability of adequate water supply in terms of both quantity and quality is essential for human existence. However, our exploitation of water resources to fulfill the growing need of man has exerted tremendous pressure, thereby deteriorating its quality substantially. Hence, conservation of water has become of utmost importance. The water pollution is thus no longer considered to be an aesthetic problem, but a serious economic and public health problem as well. Unfortunately, raw or inadequately treated sewage of millions of people still flow into our lakes and rivers, creating several kinds of disorders. The release of discharge of large number of pollutants, especially heavy metals and pesticides, pose a threat to human life (Saikia et al., 1988). Pollution of aquatic environment by heavy metals is an extremely important and serious problem and has attracted the attention of the scientists all over the world.

Industrial, agriculture and communal wastewater containing alarming high levels of heavy metals including cadmium $(\mathrm{Cd})$ compounds enter into different water reservoirs without their prior treatment. This has resulted in higher concentrations of heavy metal residues in many fish culture ponds in different parts of India (Kumar et al., 2007). Cadmium is a non-biodegradable heavy metal and is toxic to aquatic organisms at a low concentration in culture system (Burger, 2008; Ng and Wood, 2008). Major sources of this toxicant include Ni$\mathrm{Cd}$ and Ag-Cd batteries manufacturing plants, sewage sludge and lead mining and 


\section{B.A. Dar, T.A. Qureshi and R. Khaliq / Our Nature (2011) 9: 83-88}

processing units (Kumar et al., 2007). Phosphate fertilizers also contain high level of cadmium, and therefore, run-off from agricultural land can also pollute the aquatic environment (Cherian and Goyer, 1989). Its bioaccumulation and biomagnification potential via food web pose serious public health risk to fish consumers (Viana et al., 2005).

\section{Material and methods}

Indian catfish, Clarias batrachus was selected for the purpose of present study as it is hardy and bottom feeder. Specimens of this fish were collected from the fish markets of Bhopal. Disease free and healthy fishes were selected for experimentation. Immediately after bringing into laboratory, they were treated with $0.01 \% \quad \mathrm{KMnO}_{4}$ solution for 15 minutes and then transferred to plastic pools of $500 l$ capacity containing non-chlorinated water where they were kept for fifteen days for acclimatization with the $\mathrm{pH}$ range of 6.95 to 7.60 and temperature ranging from 16 to $24^{\circ} \mathrm{C}$.

\section{Experimental design}

Three groups of fishes were maintained for a maximum period of 60 days. Group (I) was kept as unexposed control and the group (II) was exposed to $4 \mathrm{ppm}(\approx 4 \%$ of 96 $\mathrm{h} \mathrm{LC}_{50}$ ) and group (III) was exposed to 8 ppm $\left(\approx 8 \%\right.$ of $\left.96 \mathrm{~h} \mathrm{LC}_{50}\right)$ cadmium chloride, $\left(\mathrm{CdCl}_{2}\right.$ MERCK, Mumbai, India; Purity 99\%). Exposure concentrations were decided on the basis of $96 \mathrm{~h} \mathrm{LC}_{50}$ value of $\mathrm{CdCl}_{2}$ which was determined to be 103 ppm. The exposure medium was changed every alternate day to maintain the desired concentration of $\mathrm{CdCl}_{2}$. The water in control group was also changed at the same time. On completion of one month of exposure, three fishes were randomly selected from control and 3 from exposed groups were sacrificed. The rest of the fishes were sacrificed after two months of exposure.

\section{Histopathological study}

Liver and kidney of the controlled and treated fishes were removed aseptically and preserved in $10 \%$ buffered formalin solution. Preserved tissues were washed under tap water for $24 \mathrm{~h}$ to remove formalin, dehydrated, clarified with xylene and embedded in paraffin blocks. They were cut at 4-5 $\mu \mathrm{m}$ thickness by using rotatory microtome and stained routinely with haematoxylin and eosin ( $\mathrm{H}$ and $\mathrm{E})$ for histopathological examination (Luna, 1968). Stained histopathological sections were examined under Olumpus research microscope. Histopathological changes observed were photographed and interpreted in comparison to the work of others.

\section{Results}

Histological studies revealed that the liver sections from control fishes showed normal histoarchitecture, liver is characterized by polygonal shaped hepatocytes with granular cytoplasm and centrally placed round nuclei. Hepatocytes were arranged in well organized hepatic cords and separated by narrow blood sinusoids (Fig. 1). Liver of fishes exposed to $4 \mathrm{ppm}$ and $8 \mathrm{ppm}$ cadmium chloride for 30 days resulted in the loosening of hepatic tissue, vacuolated cytoplasm, enucleated and distended hepatocytes and the centrally situated nuclei have shifted to the periphery of the cells (Figs. 2, 3). Liver of fishes exposed to 4 ppm and 8 ppm cadmium chloride for 60 days resulted in severe loosening and necrosis of hepatic tissue, hepatic cells lost their original shape, got excessively distended and vacuolated. Enucleation took 
B.A. Dar, T.A. Qureshi and R. Khaliq / Our Nature (2011) 9: 83-88
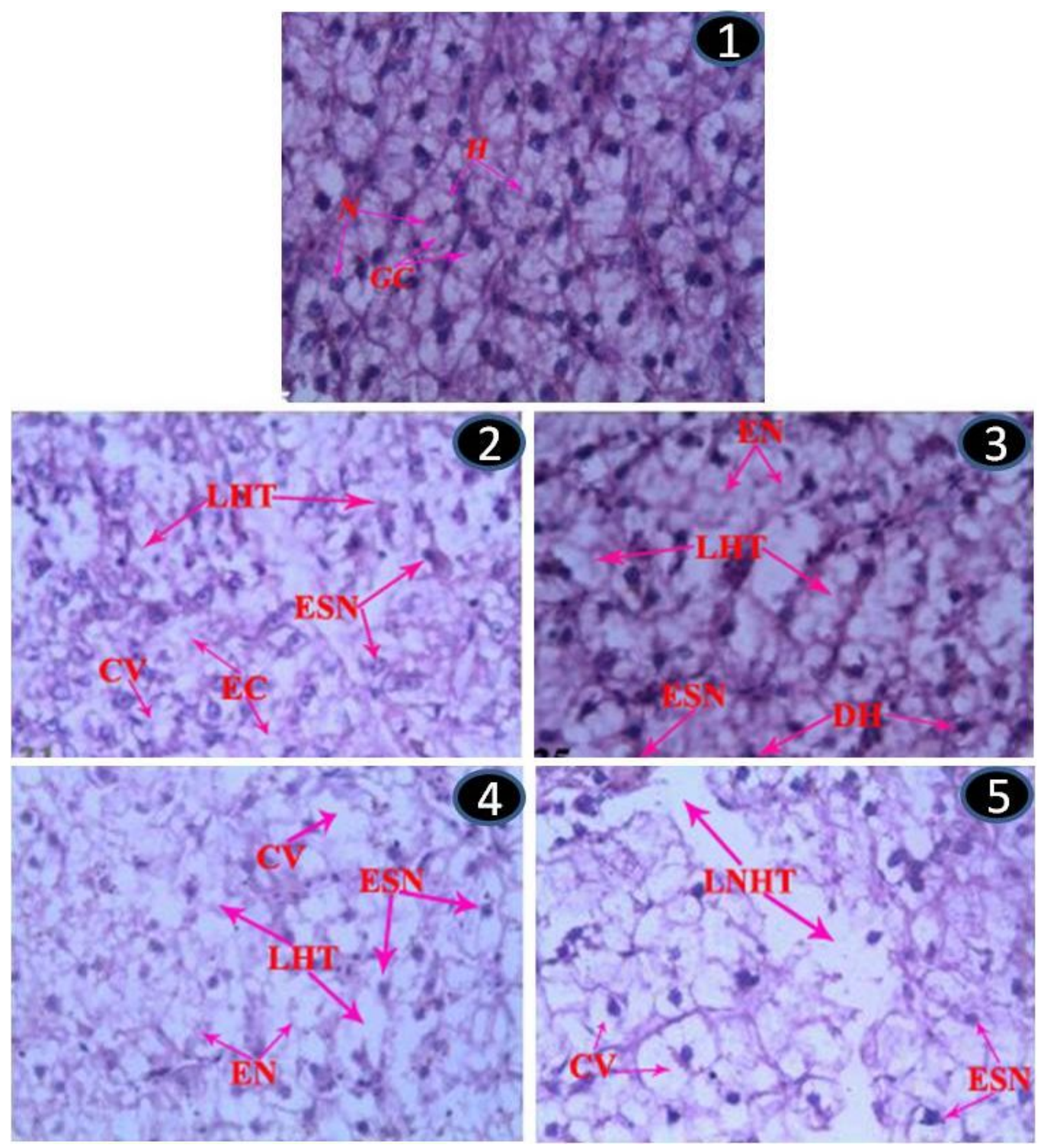

Figures: 1-5. (1). Liver structure of control fish showing hepatocytes $(\mathrm{H})$ with granular cytoplasm (GC) and

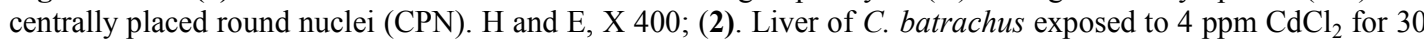
showing loosening of hepatic tissue (LHT), cytoplasmic vacualation (CV), eccentrically situated nuclei (ESN)

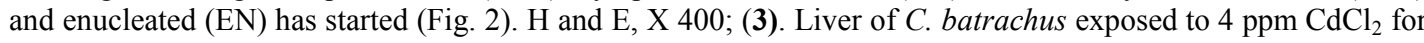
60 days showing excessive loosening of hepatic tissue (LHT), damaged hepatocytes (DH) and eccentrically situated nuclei (ESN), cytoplasmic vacuolation (CV) and enucleation (EN) (Fig. 3). H and E, X 400; (4). Liver of $C$. batrachus exposed to $8 \mathrm{ppm} \mathrm{CdCl}_{2}$ for 30 days showing severe loosening of hepatic tissue (LHT), eccentrically situated nuclei (ESN), cytoplasmic vacuolation (CV) and distended hepatic cells (Fig. 4). H and E,

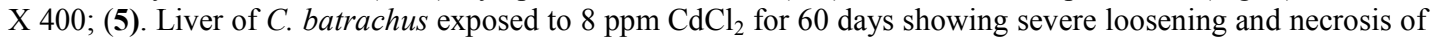
hepatic tissue (LNHT), eccentrically situated nuclei (ESN) and hepatic cells excessively distended and vacuolated (HCEDV) (Fig. 5). H and E, X 400. 


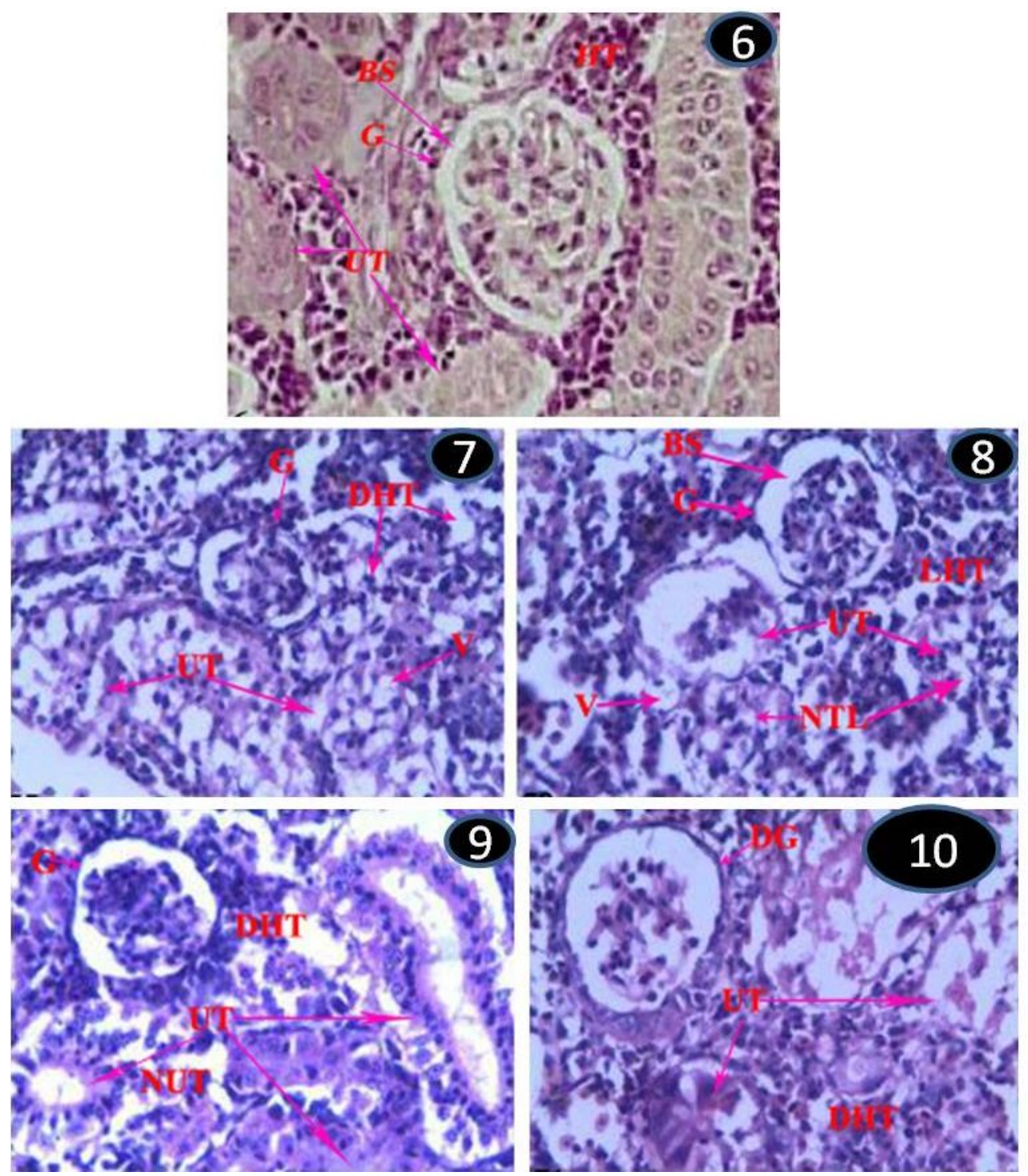

Figures:5-10. (6). Kidney structure of control fish: showing well built haemopoietic tissue (HT), uriniferous tubules (UT) and glomerulus (G) with clear Bowman's (BS) H and E, X 400; (7). Kidney of C. batrachus exposed to $4 \mathrm{ppm} \mathrm{CdCl}_{2}$ for 30 days showing damaged haemopoitic tissue (DHT), uriniferous tubules (UT), vacuolation (V) and glomeruli (G) (Fig. 2). $\mathrm{H}$ and $\mathrm{E}, \mathrm{X} 400 ;(8)$. Kidney of C. batrachus exposed to $4 \mathrm{ppm}$ $\mathrm{CdCl}_{2}$ for 60 days showing loosening of haemopoietic tissue (LHT), clustering of cells (CC), damaged uriniferous tubules (DUT), vacuolation (V), narrowing of tubular lumen (NTL) and expansion of Bowman's

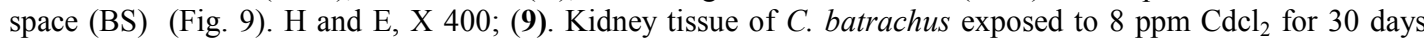
showing severely damaged haemopoietic tissue (DHT), uriniferous tubules (UT), necrosis of epithelial layer of uriniferous tubules (NUT) and deshaped glomeruli (DG) (Fig. 10). H and E, X 400; (10). Kidney tissue of $C$. batrachus exposed to $8 \mathrm{ppm} \mathrm{Cdcl}_{2}$ for 60 days showing severely damaged haemopoietic tissue (HT), uriniferous tubules (UT) and extremely damaged glomeruli (DG) (Fig. 5). H and E, X 400. 
place in majority of cells and the centrally situated nuclei shifted to the periphery of the cells (Figs. 4, 5).

Histological studies revealed that the kidney sections from control fishes showed normal histoarchitecture, kidney is characterized by well built haemopoietic tissue, uriniferous tubules and glomerulus with clear Bowman's capsule (Fig. 6). Kidney of fishes exposed to $4 \mathrm{ppm}$ and 8 ppm cadmium chloride for 30 days resulted in the Loosening of haemopoietic tissue, uriniferous tubules have lost their original appearance, vacuolated cytoplasm. The cells constituting the wall of uriniferous tubules have become completely destroyed. The lumen of uriniferous tubules has become greatly shrunken and deshaped. Expansion of space has taken place inside the renal corpuscle (Figs. 7, 8). Kidney of fishes exposed to $4 \mathrm{ppm}$ and $8 \mathrm{ppm}$ cadmium chloride for 60 days resulted in loss of compactness of haemopoietic tissue as its cells got scattered, uriniferous tubules and glomeruli got deshaped and degenerated (Figs. 9, 10).

\section{Discussion}

The present study revealed that cadmium chloride exposure induced histopathological alterations in kidney and liver of a freshwater catfish, Clarias batrachus, severity of the lesions was dose and duration dependent. Under present investigation, it has been observed that the liver of fishes exposed to $4 \mathrm{ppm}$ and $8 \mathrm{ppm}$ cadmium chloride for 30 and 60 days exhibited several histological alterations like deshaping of hepatocytes, eccentric position of nuclei, enucleation, development of vacuoles in cell cytoplasm and necrosis of hepatic tissue. The magnitude of changes increased in proportion to increased dose and time period. Similar results have been reported by Rani and Ramanmurthi (1989) in Tilapia mossambica (Oreochromis mossambicus) exposed to cadmium chloride at 5 and $50 \mathrm{ppm}$ for $1,7,15$ and 30 days, Dyk et al. (2007) in Oreochromis mossambicus exposed to cadmium and zinc, Mishra and Mohanty (2008) in liver of Channa punctatus exposed to hexavalent chromium, Pantunga et al. (2008) in Clarias gariepinus exposed to cadmium. Thopan et al. (2003) in White Sea bass, Lates calcarifer exposed to $5 \mathrm{mg} / \mathrm{l}$ cadmium chloride for 3 weeks. These findings lend support to the observations of present author.

Under present investigation, it has been observed that the kidney of fishes exposed to $8 \mathrm{ppm}$ cadmium chloride for 30 and 60 days exhibited several histological alterations like loosening, formation of clusters and lumps in haemopoietic tissue, deshaping of uriniferous tubules, narrowing of tubular lumen, vacuolization and degeneration of the cells of uriniferous tubules, increase of space in renal corpuscles and shrinkage in glomeruli. Severity in alterations increased in proportion to increased dose and time period. Similar results have been reported by Cengiz (2006) in Cyprinus carpio after acute exposure to deltamethrin. Giria et al. (2007) in European sea bass (Dicentrachcus labrax) after different cadmium concentrations exposure (4.47, 5.63, 7.08 and $8.91 \mathrm{mg} / \mathrm{l})$ for 24 and 48 hours. Mishra and Mohanty (2008) in Channa punctatus exposed to hexavalent chromium.

\section{Conclusion}

Exposure to sublethal concentrations of Cadmium chloride, thus, caused dose and duration-dependent histopathological 


\section{B.A. Dar, T.A. Qureshi and R. Khaliq / Our Nature (2011) 9: 83-88}

alterations in the liver and kidney of Clarias batrachus. The lesions in these vital organs might have resulted in physiologic and metabolic dysregulations, which further led to behavioral alterations and growth impairment. In the long-run, therefore, cadmium chloride exposures to even sublethal concentrations may pose serious threat to fish health and affect their population.

\section{Acknowledgement}

Authors are thankful to Department of Zoology and Applied Aquaculture, Barkatullah University, Bhopal, for providing infrastructure facilities.

\section{References}

Burger, J. 2008. Assessment and management of risk to wildlife from cadmium. Sci. Total Environ. 389: 37-45.

Cengiz, E.I. 2006. Gill and kidney histopathology in the freshwater fish Cyprinus carpio after acute exposure to deltamethrin. Environmental Toxicology and Pharmacology 22(2): 200-204.

Cherian, M.G. and R.A. Goyer 1989. Cadmium toxicity: Comments. Toxicology 3: 191.

Dyk, J.C.Van., G.M. Pieterse, J.H.J.Van Vuren 2007. Histological changes in the liver of Oreochromis mossambicus after exposure to cadmium and zinc. Ecotoxicology and Environmental Safety. 66: 432-440.

Giari, L., M. Manera, E. Simoni and B.S. Dezfuli 2007. Celluar alterations in different organs of European sea bass (Dicentrarchus labrax) exposed to cadmium. Chemosphere 67(6): 11711181.

Kumar, P., Y. Prasad, A.K. Patra and D. Swarup
2007. Levels of cadmium and lead in tissues of freshwater fish (Clarias batrachus L.) and chicken in Western UP (India). Bull. Environ. Contam. Toxicol. 79(4): 396-400.

Luna, L.C. 1968. Manual of histologic staining methods. Armed Forces Institute of Pathology, $3^{\text {rd }}$ ed. McGraw Hill Book Company, New York.

Mishra, A.K. and B. Mohanty 2008. Acute toxicity impacts of hexavalent chromium on behavior and histopathology of gill, kidney and liver of the freshwater fish, Channa punctatus (Bloch). Environmental Toxicology and Pharmacology 26(2): 136-141.

Ng, T.Y.T. and C.M. Wood 2008. Trophic transfer and dietary toxicity of $\mathrm{Cd}$ from the oligochaete to the rainbow trout. Aquat. Toxicol. 87(1): 47-59.

Pantunga, N., K.G. Helander, H.F. Helander and V. Cheevaporna 2008. Histopathological alterations of hybrid Walking catfish (Clarias macrocephalus $\mathrm{x}$ Clarias gariepinus) in acute and subacute cadmium exposure. Environment Asia 1: 22-27.

Rani, U.A. and R. Ramanmurthi 1989. Histopathological alterations in the liver of freshwater teleost Tilapia (Oreochromis mossambicus) in response to cadmium toxicity. Ecotoxicology and Environmental Safety 17: 221226.

Saikia, D.K., R.P. Mathur and S.K. Srivastava 1988 Heavy metal in water and sediments of upper Ganga. Indian Journal of Environmental Helath 31(1): 11-17.

Thopan, S., M. Kruatrachue, E.S. Upatham, P. Pokethitiyook, S. Sahaphong and S. Jaritkhuan 2003. Histopathological alterations of white seabass, Lates calcarifer, in acute and subchronic cadmium exposure. Environmental Pollution 121(3): 307-20.

Viana, F., R. Huertas and E. Danulat 2005. Heavy metal levels in fish from coastal waters of Uruguay. Arch. Environ. Contam. Toxicol. 48(4): 530-537. 